Article

\title{
Estuarine Macrofauna Affects Benthic Biogeochemistry in a Hypertrophic Lagoon
}

\author{
Tobia Politi ${ }^{1, *}$, Mindaugas Zilius ${ }^{1,2}$, Giuseppe Castaldelli ${ }^{2}$, Marco Bartoli ${ }^{1,3}$ (i) and \\ Darius Daunys ${ }^{1}$ \\ 1 Marine Research Institute, Klaipeda University, 92294 Klaipeda, Lithuania; \\ mindaugas.zilius@jmtc.ku.lt (M.Z.); marco.bartoli@unipr.it (M.B.); darius.daunys@jmtc.ku.lt (D.D.) \\ 2 Department of Life Science and Biotechnology, Ferrara University, 44121 Ferrara, Italy; ctg@unife.it \\ 3 Department of Chemistry, Life science and Environmental Sustainability, Parma University, \\ 43124 Parma, Italy \\ * Correspondence: tobia.politi@jmtc.ku.lt; Tel.: +39-349-557-5412
}

Received: 24 April 2019; Accepted: 4 June 2019; Published: 7 June 2019

\begin{abstract}
Coastal lagoons display a wide range of physico-chemical conditions that shape benthic macrofauna communities. In turn, benthic macrofauna affects a wide array of biogeochemical processes as a consequence of feeding, bioirrigation, ventilation, and excretion activities. In this work, we have measured benthic respiration and solute fluxes in intact sediment cores with natural macrofauna communities collected from four distinct areas within the Sacca di Goro Lagoon (NE Adriatic Sea). The macrofauna community was characterized at the end of the incubations. Redundancy analysis (RDA) was used to quantify and test the interactions between the dominant macrofauna species and solute fluxes. Moreover, the relevance of macrofauna as driver of benthic nitrogen $(\mathrm{N})$ redundancy analysis revealed that up to $66 \%$ of the benthic fluxes and metabolism variance was explained by macrofauna microbial-mediated $\mathrm{N}$ processes. Nitrification was stimulated by the presence of shallow (corophiids) in combination with deep burrowers (spionids, oligochaetes) or ammonium-excreting clams. Deep burrowers and clams increase ammonium availability in burrows actively ventilated by corophiids, which creates optimal conditions to nitrifiers. However, the stimulatory effect of burrowing macrofauna on nitrification does not necessarily result in higher denitrification as processes are spatially separated.
\end{abstract}

Keywords: fluxes; denitrification; macrofauna; functional diversity; Sacca di Goro Lagoon

\section{Introduction}

Bioturbation by benthic macrofauna-which includes a wide set of different processes among which burrow construction, ventilation, bioirrigation, sediment reworking, and biodeposition-makes sedimentary processes variable and complex [1-5]. Macrofauna communities display different adaptations to live within or on the surface sediment and produce sometimes contrasting effects on microbial processes, depending upon functional traits and tolerance to environmental stress. Macrofauna activity may determine the fate of nutrients and their transfer rates among environmental compartments [6,7]. Depending on the species and their vital habitats, associated bacterial processes can be accelerated or slowed down (e.g., anaerobic ammonium oxidation-anammox) [8,9]. Bioturbating macrofauna communities are responsible for the rearrangement of the original microbial stratification within the sediment by creating and destroying the oxic and anoxic microenvironments in the sediment, and also by direct action on the physical properties of colonized substrates [4]. Complex and species-rich macrofaunal communities or, on the other hand, communities dominated by few key species govern the ecosystem functioning in various ways. Nevertheless, species that seem redundant under 
natural conditions may be important for ecosystem functioning when ecosystems are disturbed [10]. The understanding of the biogeochemical dynamics in environments characterized by high biodiversity is strongly limited by the complex and multiple interactions among species [11]. In strongly anthropized environments, generally associated with a strong loss of biodiversity, identification of important ecological niches is even more difficult. Grouping the diversity of benthic macrofauna into functional groups, and no longer referring to single species, and identifying their single contribution to the benthic ecosystem can be a solution to the complexity of this type of study. Equally, with the appropriate functional attributions at different benthic groups, it will be easier to model the entire ecosystem [12].

A number of previous studies were targeting a heterogenous set of parameters including dissolved oxygen $\left(\mathrm{O}_{2}\right)$, carbon dioxide $\left(\mathrm{TCO}_{2}\right)$, various nitrogen $(\mathrm{N})$, phosphorus, silica forms, chlorophyll, and functional genes [13-16]. A large body of scientific work has clearly defined, sometimes at the microscale, how burrowers via intermittent ventilation import $\mathrm{O}_{2}$ into their burrows and temporally enhance microbial aerobic activity, or how filter-feeders increase sedimentary organic matter via feces and pseudofeces production $[17,18]$. Nevertheless, majority of these studies were built on laboratory experiments, with reconstructed sediments and a single macrofauna species [16,19-22]. While such approach enables to characterize target organisms and reduces background noise (sediment heterogeneities, presence of non-target macrofauna groups, etc.), the overall system layout is far from that observed in nature. For example, oversimplified communities (e.g., a single population) do not host multiple ecological interactions present among organisms (including predation, competition, facilitation, various host-microbe associations). Furthermore, sediment sieving removes reactive pools of organic matter, changing the physical and chemical gradients in sediments. Homogenization also alters the vertical distribution of the organic matter quality, redistributing and diluting high quality surface sediment organic matter along the sediment horizon. The addition of macrofauna in such sediments generally results in high stimulation of processes like nutrient regeneration. These effects may partly be the consequence of burrow construction, while in situ burrow environments are aged and well-structured in terms of microbial community composition [23]. Short-term experiments with reconstructed sediments therefore cannot fully reproduce what happens in situ, since the development of bacteria communities along burrows may take weeks and may undergo variations along the life cycle of burrowers [23]. To overcome such limitations, an alternative approach is to collect and incubate undisturbed cores with natural abundance and composition of macrofauna [24-26]. A large number of replicate cores can be incubated and sieved at the end of measurements in order to retrieve macrofauna and analyze relationships among macrofauna and biogeochemical processes a posteriori.

In estuarine systems, the understanding of the role of macrofauna communities on benthic N-cycling is a keystone, due to its large inputs from catchments and potentially large macrofauna-mediated microbial $\mathrm{N}$ losses [27-31]. It is well known that macrofauna actively contribute to the translocation and transformations of $\mathrm{N}$ within and among different compartments of aquatic ecosystems, stimulating microbial processes [32,33]. However, some species, more than others, have stronger effects on microbial dissimilative $\mathrm{N}$ paths [34,35]. The study of the effects of macrofauna communities on benthic $\mathrm{N}$-cycling is challenging as macrofauna might produce contrasting effects on the multiple oxic and anoxic microbial $\mathrm{N}$ transformations.

In this work, intact sediment cores were randomly collected from four sites representative of different dominating areas within a hypertrophic coastal lagoon. The main aim was to compare key functional characteristics at the four sites and highlight how macrofauna shape microbial respiration and nutrient regeneration rates, with a special focus on benthic $\mathrm{N}$-cycling. To this purpose, we used multiple approaches, including flux measurements, isotope pairing technique, characterization of macrofauna community, and multivariate analysis.

\section{Materials and Methods}

The Sacca di Goro lagoon is a shallow (average depth $1.5 \mathrm{~m}$ ) water embayment $\left(27 \mathrm{~km}^{2}\right)$ of the Po River Delta, situated in the norther part of the Adriatic Sea (Figure 1). This lagoon is a brackish system 
with pronounced daily variations of salinity and nutrient concentrations resulting from microtidal forcing (tidal amplitudes vary up to $0.9 \mathrm{~m}$ ) and freshwater inputs from the Po di Volano and Po di Goro rivers, and saline water input from the Adriatic Sea.
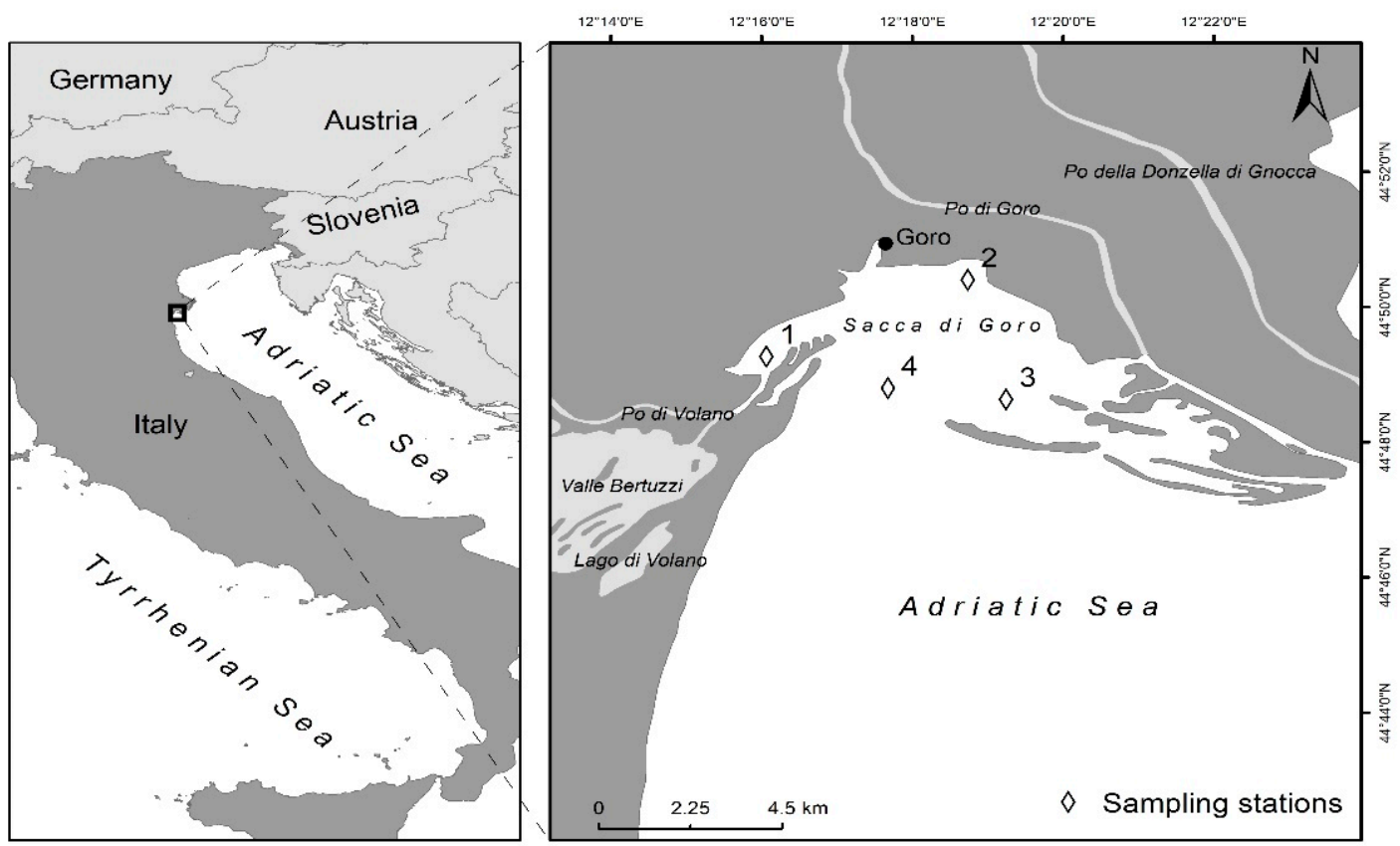

Figure 1. Map of the Sacca di Goro Lagoon and location of sampling sites.

The Sacca di Goro Lagoon has been intensively studied as one of the most economically important farming sites of the clam Vanerupis philippinarum in Europe, but also in a context of dystrophic events threated by this activity [36-38]. Studies mainly focused on the lagoon biogeochemistry [36-40], on the ecophysiology of blooming macroalgae [41], on meio- and macrofauna communities [42,43], and on ecosystem-level ecological processes (e.g., net ecosystem metabolism, sink-source functions [44]). Only a few studies have linked biogeochemical processes to macrofauna activity. However, these studies almost exclusively considered the introduced species V. philippinarum. To our knowledge, this is the first study addressing macrofauna biodiversity-benthic functioning relationship in the Sacca di Goro Lagoon.

The Sacca di Goro Lagoon is generally divided into three different zones: (1) the western part that is affected by freshwater inputs from the Po di Volano River, which leads to lower salinity and wider salinity fluctuations; (2) the central part that is connected directly to the Adriatic Sea via a $1 \mathrm{~km}$ wide mouth, therefore it is flushed by seawater; and (3) the eastern part $\left(10 \mathrm{~km}^{2}\right)$, called the Valle di Gorino, which is separated from the sea by a sand barrier and receives freshwater inputs from the Po di Goro. This eastern zone is very shallow (maximum depth $1 \mathrm{~m}$ ) but represents about half the surface of the entire lagoon. It is characterized by a relatively low salinity and higher water temperatures. The Sacca di Goro Lagoon sediment composition reflects a typical alluvial system: muds with high clay and silt contents in the northern and central zones and sand and sandy-muds bottom in the southern shore-line and eastern zone. A limited water circulation and a constant and high anthropogenic nutrients load from two rivers and secondary channels lead this lagoon to severe eutrophication processes and dystrophic events [37]. Diffuse runoff from agricultural activities within the Po river basin may lead to nitrate $\left(\mathrm{NO}_{3}{ }^{-}\right)$concentrations up to $200 \mu \mathrm{M}$, sustaining frequent blooms of the seaweeds Ulva sp., Gracilaria sp., and Cladophora sp., especially in the easternmost shallow area, whilst phytoplankton blooms prevail in the deeper central zone [45].

The studies on composition and distribution of the macrobenthic community in the Sacca di Goro Lagoon resulted in identification of 38 macrofauna taxa, representing 5 phyla [43,46-48]. Gastropods, 
amphipods, and chironomid larvae dominate the macrofauna in terms of abundance, while bivalves represent biomass dominant group of organisms. Macrofauna abundance undergo considerable seasonal variations due to development of macroalgae and $\mathrm{O}_{2}$ depletion in the near-bottom water layer and sediment.

\subsection{Intact Core Collection and Benthic Flux Measurement}

At four sites within the lagoon, eight large (i.d. $8.4 \mathrm{~cm}$, length $30 \mathrm{~cm}$, for flux measurements) and three small cores (i.d. $4.6 \mathrm{~cm}$, length $25 \mathrm{~cm}$, for sediment characterization) were randomly collected in May 2013 by hand corer, covering dominating macrofauna assemblages along environmental gradients (Figure 1). Sediments and water height in the large cores were levelled to 15 and $10 \mathrm{~cm}$, respectively, so that the water volume overlying sediments was nearly $0.5 \mathrm{~L}$. In addition, $80 \mathrm{~L}$ of in situ water were collected from each station for core maintenance during transportation, pre-incubation, and incubation. Within 4 hours of sampling, all cores were transferred to the laboratory where they were maintained overnight submerged into four tanks containing in situ water $\left(20^{\circ} \mathrm{C}\right)$. Each core was provided with a Teflon-coated magnetic bar suspended $5 \mathrm{~cm}$ above the sediment-water interface and driven by an external magnet rotating at $40 \mathrm{rpm}$. The magnetic bars ensured water mixing within each core, avoiding sediment resuspension. The water in each tank was also stirred by aquarium pumps in order to maintain $\mathrm{O}_{2}$ saturated conditions during pre-incubation period. The large cores were used to measure benthic metabolism $\left(\mathrm{O}_{2}, \mathrm{TCO}_{2}\right.$ and manganous manganese $\left.\left(\mathrm{Mn}^{2+}\right)\right)$ and net ammonium $\left(\mathrm{NH}_{4}{ }^{+}\right)$, combined nitrate and nitrite $\left(\mathrm{NO}_{\mathrm{x}}{ }^{-}\right)$, and soluble reactive phosphorus (SRP) fluxes in the dark. After the overnight pre-incubation, a gas-tight top lid was placed on each core, without gas headspace, and the 4-hour incubation started. The incubation time was set in order to keep $\mathrm{O}_{2}$ within $20 \%$ of initial concentration. Initial water samples were taken in triplicate from each tank, whereas final water samples were taken from the water phase of each core [49]. At the beginning and at the end of the incubation a $20 \mathrm{~mL}$ aliquot of water was collected from each core, transferred and flushed into $12 \mathrm{~mL}$ exetainer (Labco, UK), and fixed with $100 \mu \mathrm{L}$ of $7 \mathrm{M} \mathrm{ZnCl}_{2}$ for dissolved $\mathrm{O}_{2}$ measurements. Thereafter, three more aliquots of $50 \mathrm{ml}$ were immediately filtered (Whatman GF/F filters) and transferred into scintillation vials and exetainers for nutrient, $\mathrm{TCO}_{2}$, and $\mathrm{Mn}^{2+}$ analysis, respectively. Aliquots for $\mathrm{Mn}^{2+}$ analyses were acidified with $50 \mu \mathrm{l}$ of ultra-pure concentrated $\mathrm{HNO}_{3}$. The solute exchange at the sediment-water interface were calculated according to the Equation (1):

$$
F_{x}=\frac{\left(C_{f}-C_{i}\right) \times V}{A \times t}
$$

where $F_{x}\left(\mu \mathrm{mol} \mathrm{m}{ }^{-2} h^{-1}\right)$ is the flux of the chemical species $x, C_{i}$ and $C_{f}\left(\mu \mathrm{mol} \mathrm{L}^{-1}\right)$ are concentrations of chemical species $x$ at the beginning and at the end of incubation, respectively, $V(L)$ is the water volume in the core, $\mathrm{A}\left(\mathrm{m}^{2}\right)$ is the surface of the sediment, and $\mathrm{t}(\mathrm{h})$ is incubation time.

Small cores were used to measure sediment properties in the upper layer $(5 \mathrm{~cm})$. Sediments were extruded from each core, sliced, and homogenized. After homogenization, $5 \mathrm{~mL}$ of sediment subsample was dried at $60{ }^{\circ} \mathrm{C}$ for $48 \mathrm{~h}$ to determine bulk density and porosity. Thereafter, dried sediment subsamples were analyzed for organic carbon $\left(\mathrm{C}_{\text {org }}\right)$ and total nitrogen $(\mathrm{TN})$.

\subsection{Denitrification Measurement with Isotope Pairing Technique}

After flux measurements, the cores were submerged with the top open for 3 hours in in situ-aerated and well-mixed water. Thereafter, we performed a second incubation targeting the rates of denitrification measurements with isotope pairing technique [50]. This approach allows to measure total denitrification (D14) in and the contribution of denitrification supported by overlaying water $\mathrm{NO}_{3}{ }^{-}\left(\mathrm{D}_{\mathrm{w}}\right)$ and denitrification coupled with nitrification $\left(\mathrm{D}_{\mathrm{n}}\right)$. Briefly, stock solution of $15 \mathrm{mM}$ ${ }^{15} \mathrm{NO}_{3}{ }^{-}\left(98 \%\right.$ of $\mathrm{K}^{15} \mathrm{NO}_{3}$, Cambridge Isotope Laboratories, MA, USA) was added to the water column of each core to the final concentration of $50 \mu \mathrm{M}$. To calculate the isotopic enrichment, water samples 
for $\mathrm{NO}_{3}{ }^{-}$analysis was collected prior and after to the isotope addition. Thereafter, cores were closed and incubated for 4 hours in the dark as described for nutrient flux measurements. At the end of the incubation, the whole sediment column was carefully slurred and mixed with the water column as bioturbating animals can transport ${ }^{15} \mathrm{NO}_{3}{ }^{-}$downward and stimulate nitrification and denitrification in deep layers. A glass syringe containing $50 \mathrm{~mL}$ of slurries was transferred to $12 \mathrm{~mL}$ exetainers (Labco, $\mathrm{UK}$ ), allowing abundant overflow and gas bubbles removal and fixed with $200 \mu \mathrm{L}$ of $7 \mathrm{M} \mathrm{ZnCl}_{2}$ to stop microbial activity. Immediately after the end of this second incubation, sediments from all cores were carefully sieved $(0.5 \mathrm{~mm}$ mesh size) in order to retrieve and analyze the macrofauna composition, abundance, and biomass.

\subsection{Laboratory Analysis}

Concentration of dissolved gas $\left(\mathrm{O}_{2},{ }^{29} \mathrm{~N}_{2}\right.$ and $\left.{ }^{30} \mathrm{~N}_{2}\right)$ were measured within a week from collection with a membrane inlet mass spectrometer (MIMS, Bay instruments, MD, USA) at Ferrara University [51]. Dissolved inorganic $\mathrm{N}\left(\mathrm{NH}_{4}{ }^{+}, \mathrm{NO}_{2}{ }^{-}\right.$and $\left.\mathrm{NO}_{x}{ }^{-}\right)$and SRP were measured with a continuous flow analyzer $\left(\mathrm{San}^{++}\right.$, Skalar) using standard colorimetric methods [52]. $\mathrm{NO}_{3}{ }^{-}$was calculated as the difference between $\mathrm{NO}_{\mathrm{x}}{ }^{-}$and $\mathrm{NO}_{2}{ }^{-}$. Dissolved $\mathrm{Mn}^{2+}$ was measured with a Varian atomic absorption at Parma University. $\mathrm{C}_{\text {org }}$ and TN were analyzed with an element analyzer (Thermo Electron Corporation FlashEA 1112, Thermo Fisher Scientific, Waltham, MA USA). Before measurement, samples were acidified with $1 \mathrm{~N} \mathrm{HCl}$ in order to remove carbonates.

\subsection{Multivariate Analysis}

Redundancy analysis (RDA) was used to quantify and test the interactions between the numerically dominant 7 species (explanatory variables), net solute fluxes (total $\mathrm{O}_{2}$ uptake (TOU), $\mathrm{TCO}_{2}, \mathrm{NH}_{4}{ }^{+}$, $\mathrm{NO}_{2}{ }^{-}, \mathrm{NO}_{\mathrm{x}}{ }^{-}, \mathrm{SRP}$ and $\mathrm{Mn}^{2+}$ ), and denitrification pathways (D14, Dw, and Dn) in the 32 intact cores, collected from the 4 sites. We completed this variation partitioning analysis using Partial-RDA to calculate the contribution of each site to the total variance unexplained by the first RDA approach [53]. According to [54], the total sum of canonical eigenvalues from five different RDA analyses have been used to explain the shared information, the pure effect of macrofauna presence and the pure effect of sites as a percentage of the total inertia. The significance of the environmental variables (axis) was tested against 9000 Monte Carlo permutations. Data on macrofauna communities were tested for normality assumption using the Kolmogorov-Smirnov test, while relationships between abiotic parameters and macroinvertebrate communities examined using linear regression [55].

A one-way analysis of variance (ANOVA) was used to test the significance of site in explaining variation in metabolism, net fluxes, and denitrification pathways. Validity of normality assumption and homogeneity of variance was checked using Shapiro-Wilcoxon and Cochran's test, respectively, and square root transformation was applied for data with significant heteroscedascity. A pair-wise comparison of means using the post-hoc Bonferroni test was performed for significant effects. Hierarchical cluster analysis and multidimensional-scaling (MDS) were performed on pairwise similarities between couples of samples using the Bray-Curtis similarity index in order to determine the macrofauna species complexity between and within sites [56].

All statistical analyses were performed with Brodgar 7.5.5 statistical software package.

\section{Results}

\subsection{Bottom Water and Sediment Features at the Sampling Sites}

The concentrations of dissolved nutrients displayed strong spatial variability among studied sites and differed by up to one order of magnitude (Table 1). Peak concentrations of $\mathrm{NO}_{3}{ }^{-}$, SRP, and $\mathrm{TCO}_{2}$ were observed at the brackish site 1 where river enters the lagoon. $\mathrm{NO}_{3}{ }^{-}$was the dominating form of dissolved inorganic $\mathrm{N}$ at sites 1 and 4 , whereas $\mathrm{NH}_{4}{ }^{+}$concentrations were higher at sites 2 and 3 . Salinity and nutrient content can vary dramatically on a daily basis at all sites due to tidal forcing. 
At site 4, we found relatively low salinity and high $\mathrm{NO}_{3}{ }^{-}$concentration despite its proximity to the open sea, likely due to the sampling performed at low tide when the station is influenced by freshwater inputs from the Po di Goro.

Table 1. Bottom water physico-chemical features and surface sediment $(0-5 \mathrm{~cm})$ characteristics at the sampling sites in the Sacca di Goro Lagoon. Averages \pm standard error are reported $(n=3)$.

\begin{tabular}{ccccc}
\hline PARAMETERS & SITE 1 & SITE 2 & SITE 3 & SITE 4 \\
\hline Water column & & & & \\
Temperature $\left({ }^{\circ} \mathrm{C}\right)$ & 21 & 21 & 19 & 19 \\
Salinity $(\mathrm{PSU})$ & 5 & 12 & 12 & 7 \\
$\mathrm{TCO}_{2}\left(\mathrm{mmol} \mathrm{L}^{-1}\right)$ & $5.2 \pm 0.01$ & $3.3 \pm 0.01$ & $2.6 \pm 0.01$ & $2.6 \pm 0.01$ \\
$\mathrm{NH}_{4}^{+}\left(\mu \mathrm{mol} \mathrm{L}^{-1}\right)$ & $7.1 \pm 0.12$ & $32.1 \pm 0.17$ & $31.9 \pm 0.17$ & $19.1 \pm 0.69$ \\
$\mathrm{NO}_{\mathrm{x}}^{-}\left(\mu \mathrm{mol} \mathrm{L}^{-1}\right)$ & $114.7 \pm 4.45$ & $40.8 \pm 1.67$ & $56.5 \pm 2.02$ & $52.3 \pm 3.93$ \\
$\mathrm{SRP}(\mu \mathrm{mol} \mathrm{L})$ & $2.2 \pm 0.02$ & $0.4 \pm 0.01$ & $1.1 \pm 0.01$ & $0.5 \pm 0.01$ \\
\hline Sediment & & & & \\
Type & Clayish mud & Detrital mud & Muddy sand & Fine sand \\
Porosity & $0.85 \pm 0.02$ & $0.89 \pm 0.01$ & $0.43 \pm 0.01$ & $0.50 \pm 0.03$ \\
Density $\left(\mathrm{g} \mathrm{cm}{ }^{-3}\right)$ & $1.16 \pm 0.01$ & $1.12 \pm 0.02$ & $1.83 \pm 0.02$ & $1.78 \pm 0.02$ \\
Corg $(\%)$ & $4.02 \pm 0.27$ & $7.48 \pm 0.26$ & $1.29 \pm 0.14$ & $1.42 \pm 0.14$ \\
$\mathrm{TN}(\%)$ & $0.34 \pm 0.01$ & $0.85 \pm 0.05$ & $<0.01$ & $<0.01$ \\
C:N (mass) & 11.8 & 8.8 & - & - \\
\hline
\end{tabular}

Sediment characteristics differed substantially among sampling sites reflecting sedimentation of clayish material from terrestrial origin (site 1), organic matter from decaying macroalgae (site 2), biodeposits from clams farming (site 3), and strong flushing (site 4). As a result, sites 1 and 2 were mainly muddy, site 3 consisted of muddy sand, whereas site 4 was mainly sandy (Table 1). Sites 1 and 2 had highest $C_{\text {org }}$ and TN content. At these sites, high porosity and low density values suggest high sedimentation rates, limited export, and net accumulation of material. Sediments from sites 1 and 3 appeared heavily bioturbated, with light brown halos surrounding burrows in the upper 3-5 cm, sediments from site 2 appeared black, sulfide smelling, and poorly bioturbated, whereas sediments from site 4 appeared oxidized and without redox discontinuities along the vertical profile.

\subsection{Benthic Macrofauna}

In total, 17 species or higher order taxa with an average abundance of $82 \pm 12$ ind. core ${ }^{-1}$ were found after sieving incubated sediment (see the list of species in Electronic Supplementary Materials). Abundance and taxonomic diversity differed greatly among sites (Figure 2) and macrofauna structure was more similar among cores collected within the same site, than among sites (Figure 3).

In site $1\left(1264 \pm 407\right.$ ind. $\left.\mathrm{m}^{-2}\right)$, spionids, oligochaetes, and Monocorophium insidiosum accounted for $92 \%$ of the total macrofauna abundance on average. The site was relatively homogenous in a context of taxonomic composition (Figure 3) and abundance (273-2986 ind. $\mathrm{m}^{-2}, 4-7$ taxa m$^{-2}$ ).

Site $2\left(1218 \pm 311\right.$ ind. $\left.\mathrm{m}^{-2}\right)$ had the lowest taxonomic diversity ( 8 taxa), but similar macrofauna characteristics for individual cores (561-2622 ind. $\mathrm{m}^{-2}, 3-7$ taxa $\mathrm{m}^{-2}$ ) compared to site 1. M. insidiosum, Chironomus salinarius and gammarids contributed to $79 \%$ of the total macrofauna (Figure 3 ), however with considerable variation among replicates $\left(0-1546,61-485\right.$, and 61-864 ind. core ${ }^{-1}$, respectively). Only one replicate (2(6), see Figure 3) was extremely different from the rest in this site with exclusively high $62 \%$ relative abundance ( 909 ind. core $^{-1}$ ) of Hydrobia sp.

Site $3\left(2160 \pm 263\right.$ ind $\left.\mathrm{m}^{-2}\right)$ was relatively homogenous in a context of macrofauna composition and abundance (1410-2895 ind. $\mathrm{m}^{-2}, 5-8$ taxa $\mathrm{m}^{-2}$ ) with the highest average number of individuals per core (Figure 2). M. insidiosum attained the highest abundance (455-1758 ind. $\mathrm{m}^{-2}$, with an average of $970 \pm 192$ ind. $\mathrm{m}^{-2}$ ) in the context of studied sites (Figure 3 ) and alone accounted for $45 \%$ of the total macrofauna abundance. However, the characteristic species for this site was V. philippinarum with relatively consistent abundance of $258-1228$ ind. $\mathrm{m}^{-2}$ (601 $\pm 106 \mathrm{ind} . \mathrm{m}^{-2}$ in average). 


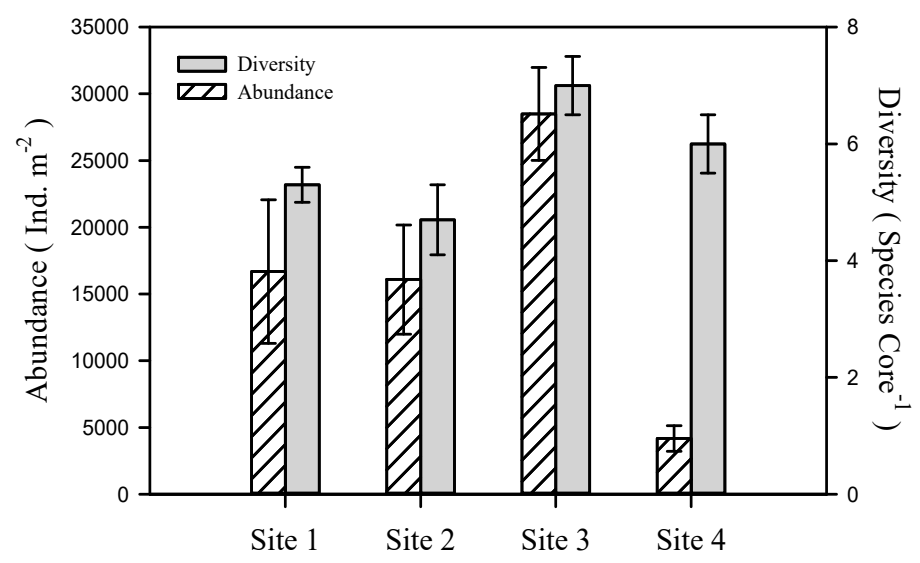

Figure 2. Taxonomic diversity (number of species per core) and total abundance of benthic macrofauna (ind. $\mathrm{m}^{-2}$ ) in incubated cores from four study sites in the Sacca di Goro Lagoon (average \pm st. error).

Site 4 (316 \pm 73 ind. $\mathrm{m}^{-2}$ ) had the lowest abundance of macrofauna individuals (Figure 2) varying between 91 and 667 ind. $\mathrm{m}^{-2}$, but the highest overall taxonomic diversity (13 taxa). At the same time, consistency of dominant macrofauna among cores was low (Figure 2). The majority of cores was dominated by spionids (4(3)-4(7), 61-364 ind. $\mathrm{m}^{-2}$; Figure 3), but other cores included V. philippinarum (4(2), 258 ind. $\mathrm{m}^{-2}$ ), musculista (4(8), 91 ind. $\mathrm{m}^{-2}$ ), and Caprelidae (4(1), 45 ind. $\mathrm{m}^{-2}$ ).

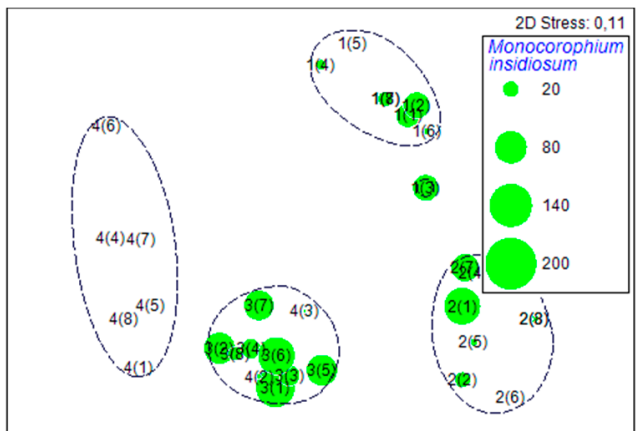

(A)

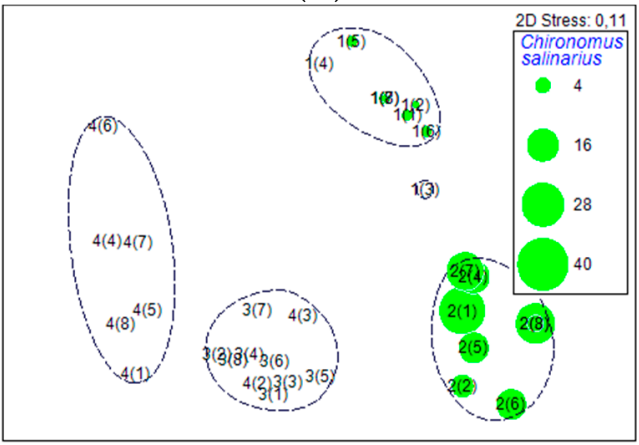

(C)

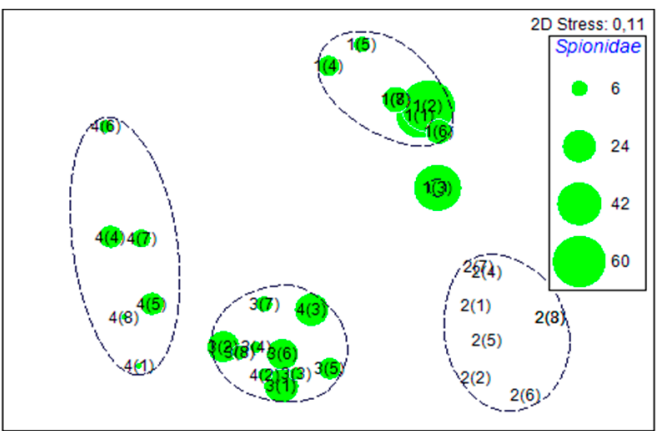

(B)

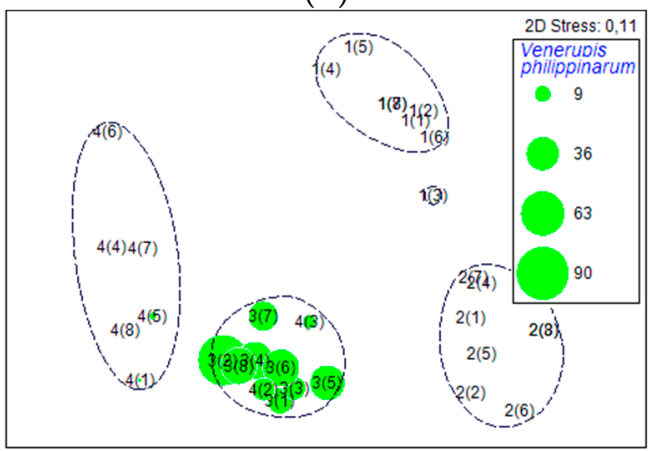

(D)

Figure 3. MDS plot according to taxonomic composition of dominating benthic macrofauna (presence/absence transformation) in incubated cores: Monocorophium insidiosum (A), Spionidae (B), Chironomus salinarius (C) and Venerupis philipinarium (D). Labels and brackets refer to site and replicate number correspondingly, and abundance of main macrofauna taxa (diameter of bubbles proportional to the abundance).

\subsection{Benthic Metabolism and Respiration}

Total $\mathrm{CO}_{2}$ production rates were similar in three out of four sites $\left(3.2 \mathrm{mmol} \mathrm{m}^{-2} \mathrm{~h}^{-1}\right.$ on average), with site 1 as only exception (One-way ANOVA, $\mathrm{F}=20.80, \mathrm{P}=0.001$ ) (Figure 4). There $\mathrm{TCO}_{2}$ uptake 
dominated likely due to sharp chemical gradients between the high carbonate content of near bottom and pore water (see Table 1). TOU ranged from 0.7 to $8.1 \mathrm{mmol} \mathrm{m}^{-2} \mathrm{~h}^{-1}$ with significant differences among sites (One-way ANOVA, $\mathrm{F}=8.308, \mathrm{P}=0.001)$. Considerably $(\mathrm{P}<0.001$ ) higher TOU was measured at sites 2 and 3 in comparison to site 4. A net $\mathrm{Mn}^{2+}$ efflux was measured at all sites; in three out of four sites, fluxes were similar with an average rate of $50 \mu \mathrm{mol} \mathrm{m}{ }^{-2} \mathrm{~h}^{-1}$. Significantly $(\mathrm{P}<0.001)$ higher efflux was found at site $2\left(170.18 \pm 33 \mu \mathrm{mol} \mathrm{m} \mathrm{m}^{-2} \mathrm{~h}^{-1}\right)$. Calculated respiratory quotients (the ratios between $\mathrm{TCO}_{2}$ and $\mathrm{TOU}$ ) at sites 2,3 , and 4 were close to unity, suggesting the dominance of aerobic metabolism.
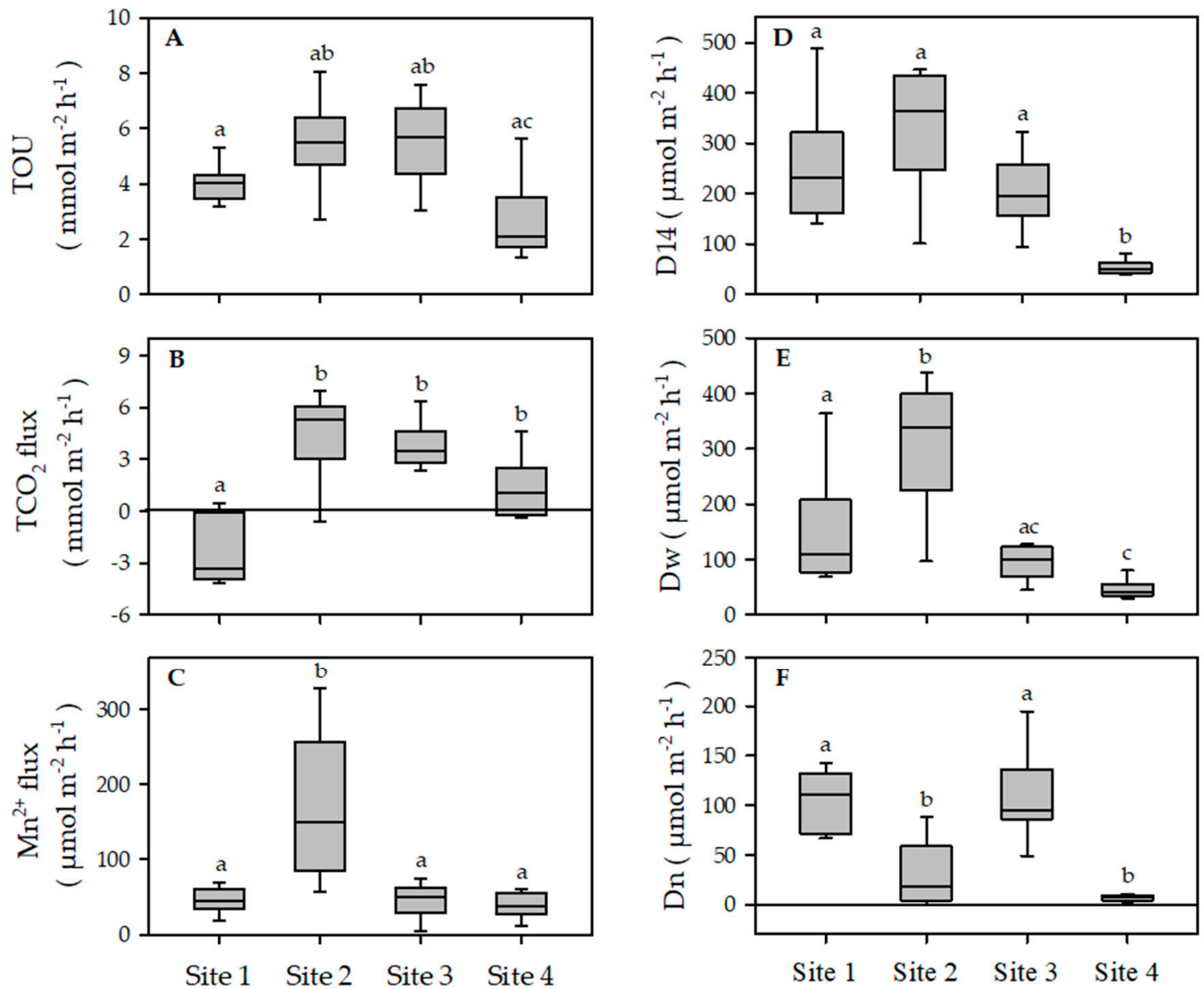

Figure 4. Total oxygen uptake (A), sediment-water fluxes of total inorganic carbon (B), manganous manganese (C), total denitrification (D) and denitrification of water column $\mathrm{NO}_{3}{ }^{-}$(E), and coupled nitrification-denitrification (F) measured at four study sites in the Sacca di Goro Lagoon (median and percentiles, $n=8$ ). Different letters indicate statistical differences among sites.

At sites 1, 2, and 3, total denitrification rates (D14) were elevated and sustained a relevant portion of total mineralization (10-20\%). D14 ranged from 37.9 to $481.0 \mu \mathrm{mol} \mathrm{m}^{-2} \mathrm{~h}^{-1}$ and differed between sites (One-way ANOVA sqrt transformed, $\mathrm{F}=20.12, \mathrm{P}<0.001)$ (Figure 4). Significantly $(\mathrm{P}<0.05)$ lower rates of D14 $\left(52.3 \pm 14.4 \mu \mathrm{mol} \mathrm{m} \mathrm{m}^{-2} \mathrm{~h}^{-1}\right)$ were observed at site 4 . In other sites, rates of D14 were similar with an average of $263.5 \pm 113.2 \mu \mathrm{mol} \mathrm{m} \mathrm{m}^{-2} \mathrm{~h}^{-1}$. The relative importance of Dw and Dn to the total rates of denitrification varied among sites (One-way ANOVA sqrt transformed, $\mathrm{F}=20.31$ and $\mathrm{F}=32.03$, respectively, $\mathrm{P}<0.001$ ), depending on availability of $\mathrm{NO}_{3}{ }^{-}$in the water column. At sites 2 and 4 , total denitrification was sustained mainly by Dw, which represented from $87 \%$ to $90 \%$ of $\mathrm{N}_{2}$ production. The share of total denitrification supported by nitrification coupled denitrification was more important at sites $1(46 \%)$ and $2(40 \%)$. The rates of Dw were in the rage of $29.4-437.9 \mu \mathrm{mol} \mathrm{m}^{-2} \mathrm{~h}^{-1}$ at the studies sites. Significantly $(\mathrm{P}<0.05)$ higher rates $\left(305.1 \pm 122.6 \mu \mathrm{mol} \mathrm{m} \mathrm{m}^{-2} \mathrm{~h}^{-1}\right)$ of Dw were measured at site 
2, while relatively lower rates $\left(45.6 \pm 16.5 \mu \mathrm{mol} \mathrm{m}^{-2} \mathrm{~h}^{-1}\right)$ were measured at sandy sediment at site 4 . Dn varied from to 0 to $194.7 \mu \mathrm{mol} \mathrm{m} \mathrm{m}^{-2} \mathrm{~h}^{-1}$ with significantly $(\mathrm{P}<0.001)$ higher rates at sites 1 and 3 $\left(106.9 \pm 36.9 \mu \mathrm{mol} \mathrm{m}^{-2} \mathrm{~h}^{-1}\right)$ as compared to sites 2 and $4\left(18.3 \pm 25.3 \mu \mathrm{mol} \mathrm{m}^{-2} \mathrm{~h}^{-1}\right)$. Denitrification of water column $\mathrm{NO}_{3}{ }^{-}$was calculated with the model proposed by Christensen et al. [57] and compared with measured rates. In three out of four sites, theoretical rates overestimate measured rates by a factor 5 , while at site 2 predicted $\left(\approx 430 \mu \mathrm{mol} \mathrm{m}^{-2} \mathrm{~h}^{-1}\right)$ and measured $\left(\approx 300 \mu \mathrm{mol} \mathrm{m}^{-2} \mathrm{~h}^{-1}\right)$ rates were closer.

\subsection{Benthic Nutrient Fluxes}

Net fluxes of $\mathrm{NH}_{4}{ }^{+}$varied from -201.4 to $917.0 \mu \mathrm{mol} \mathrm{m}{ }^{-2} \mathrm{~h}^{-1}$ and significantly differed among sites (One-way ANOVA, $\mathrm{F}=15.5, \mathrm{P}=0.001)$ (Figure 5). The highest flux $\left(641.8 \pm 215.6 \mu \mathrm{mol} \mathrm{N} \mathrm{m}{ }^{-2} \mathrm{~h}^{-1}\right)$ was measured at site $2(\mathrm{P}<0.001)$. The negative net $\mathrm{NH}_{4}{ }^{+}$fluxes were observed only at site 1 where it was significantly $(\mathrm{P}<0.05)$ lower in comparison to sites 2 and 4 . On the contrary, $\mathrm{NO}_{\mathrm{x}}$ fluxes were erratic without clear patterns among sites (One-way ANOVA, $\mathrm{F}=1.9, \mathrm{P}=0.147$ ). At site 1 , it has been measured the higher efflux of $\mathrm{NO}^{-}\left(562.8 .3 \pm 225 \mu \mathrm{mol} \mathrm{N} \mathrm{m}{ }^{-2} \mathrm{~h}^{-1}\right)$ which coincided with uptake of $\mathrm{NH}_{4}{ }^{+}\left(-30.5 \pm 44 \mu \mathrm{mol} \mathrm{m}^{-2} \mathrm{~h}^{-1}\right)$, suggesting large nitrification rates. Denitrification efficiency (DE), which is the ratio between dinitrogen $\left(\mathrm{N}_{2}\right)$ flux and the sum of $\mathrm{N}_{2}$ and dissolved inorganic $\mathrm{N} \mathrm{NH}_{4}{ }^{+}+$ $\mathrm{NO}_{\mathrm{x}}{ }^{-}$) effluxes, varied between $27.4 \%$ (at site 4 ) and $63.4 \%$ (at site 2). Sites 1 and 3 had a comparable $\mathrm{DE}(\approx 46-49 \%)$. The flux of SRP was in the range of $-26.6-57.9 \mu \mathrm{mol} \mathrm{m}{ }^{-2} \mathrm{~h}^{-1}$ without any significant (One-way ANOVA, P > 0.05) difference among sites. Overall, sediments were net sources of SRP except sea exposed sand at site 4 .
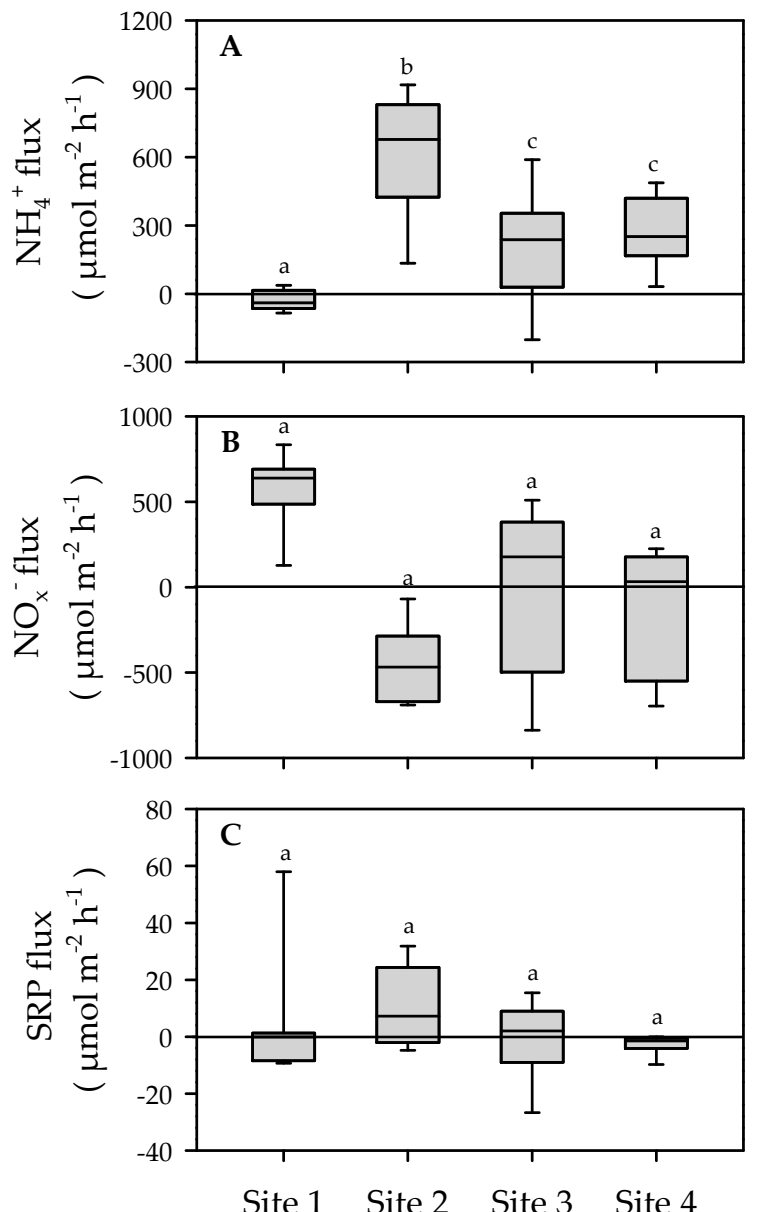

Figure 5. Sediment-water fluxes of ammonium (A), combined nitrite and nitrate (B), and soluble reactive phosphorus $(\mathbf{C})$ measured at four study sites in the Sacca di Goro Lagoon (median and percentiles, $\mathrm{n}=8$ ). Different letters indicate statistical differences among sites. 


\subsection{Macrofauna Community, Functional Traits and Benthic Ecosystem Functioning}

In order to assess the effect of benthic invertebrates on microbial processes and fluxes at the water-sediment interface, an RDA model was used. Macrofauna species were considered as explanatory variables whereas fluxes and metabolic pathways were used as response variables. The model was significant (Monte Carlo significance test of all canonical axes, $\mathrm{F}=5.6780, \mathrm{P}=0.0001$ ). The total amount of variation explained in the response variables equaled $66 \%$ (sum of all canonical eigenvalues). The first two axes (38.8\% and 13.8\%) were extracted as independent variables from the RDA. Taken together, they accounted for $79.5 \%$ of the total explained variance in biogeochemical parameters (response variables). C. salinarium contributed most to the variation (15.2\%), followed by V. philippinarum (6.2\%) and gammarids (2.4\%). The first axis was mainly correlated to chironomid larvae, gammarids, and corophiids, and was strongly but negatively correlated to spionids. The second axis was positively correlated with spionids and oligochaetes and negatively correlated to caprelids. Most of found explanatory-response variable relationships were ecologically reasonable and with a direct ecological background (see the discussion section).

The triplot (Figure 6) allows to distinguish specific correlation, between site-specific macrofauna and particular metabolic pathways and fluxes measured in the four studied areas. Benthic net fluxes of $\mathrm{Mn}^{2+}, \mathrm{NH}_{4}{ }^{+}$, and $\mathrm{TCO}_{2}$ were strongly associated to the benthic activity of gammarids and C. salinarius. Denitrification (D14, Dw, and Dn) were best explained by a model when including V. philippinarum, M. insidiosum, and caprelids (with an opposite effect) presence. The presence of V. philippinarum and M. insidiosum were also positively correlated to SRP flux and TOU. Oligochaetes, Neanthes, and spionids negatively affected $\mathrm{TCO}_{2}$ and $\mathrm{NH}_{4}{ }^{+}$fluxes.

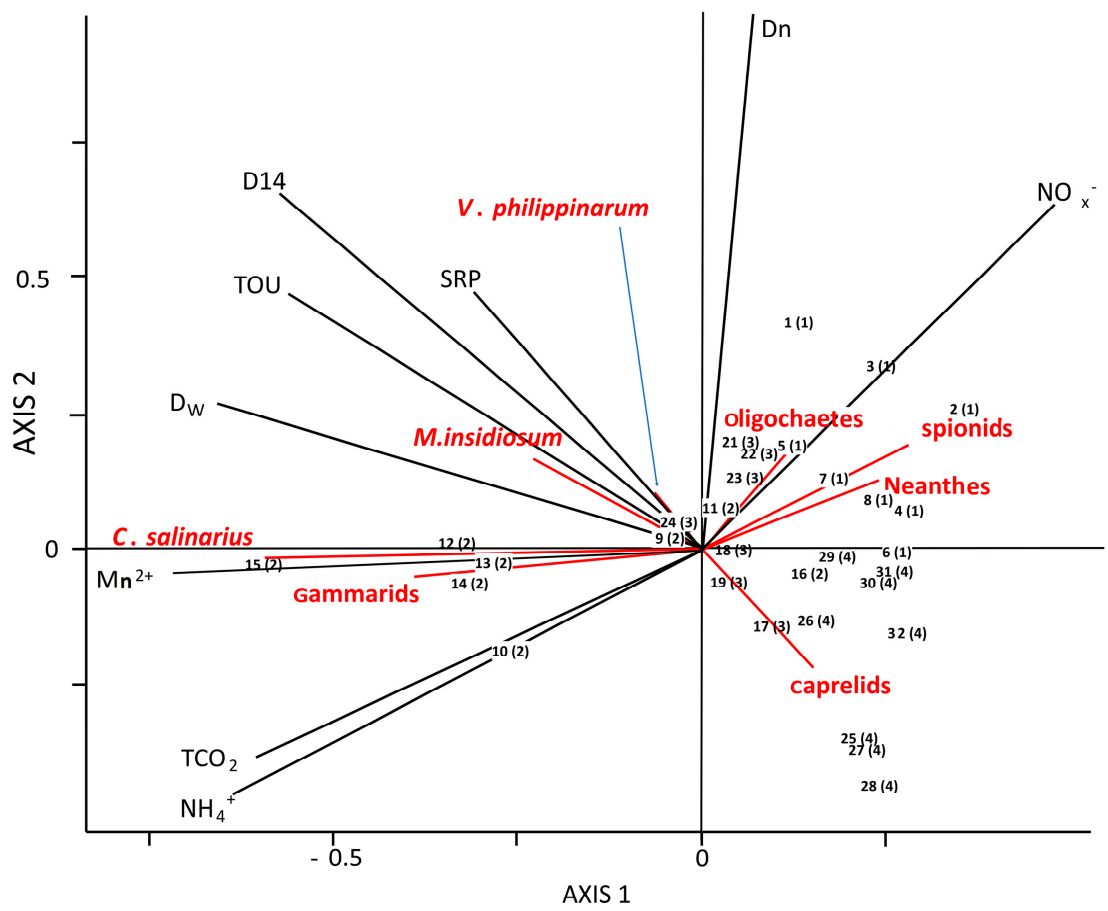

Figure 6. Distance triplot of redundancy analysis (RDA) on fluxes (TOU; $\mathrm{TCO}_{2}, \mathrm{Mn}^{2+}, \mathrm{NH}_{4}{ }^{+}, \mathrm{NO}^{-}$, and SRP) and processes (denitrification-D14, Dw, and Dn) in the Sacca di Goro Lagoon, using the eight most representative benthic macrofauna as explanatory variables (V. philippinarum, Neanthes, spionids, oligochaetes, C. salinarius, M. insidosum, gammarids, and caprelids). Numbers (1-32) indicate single cores collected from the four sampling sites. The thick arrows are the vectors of the explanatory variables. The projection of any sample onto arrows approximates the measured value in that sample.

Partial-RDA analysis (triplot not shown) was used to disentangle the pure effect of the 8 species of macrofauna (X1) from the possible effect given from the four sites (X2) taken in consideration 
(macrofauna-location portioning). Variation partitioning analysis of benthic processes explained by functional diversity and sites (as nominal explanatory variables) indicates a strong synergistic effect on the total variance explanation. The total amount of variation explained in the response variables equaled 44\% (sum of all canonical eigenvalue) (Table 2). Variable species alone explained (X1|X2) 19\% of benthic flux variation, whereas sites differences $(\mathrm{X} 2 \mid \mathrm{X} 1)$ alone explained only the $8 \%$; the sum of effects explained the $47 \%$ of the variation.

Table 2. Summary table showing variation partitioning and calculation of benthic fluxes explained by macrofauna species, sites, and joined effect. Explained variance can be portioned in $[A],[B]$, and [C]. $[\mathrm{A}]=$ percentage of variability merely explained by macrofauna; $[\mathrm{C}]=$ percentage of variability merely explained by location; [B] = percentage of variability explained by a synergistic effect.

\begin{tabular}{ccc}
\hline Predictors and Covariables & Df & $\begin{array}{c}\text { Sum of All Canonical } \\
\text { Eigenvalues (\%) }\end{array}$ \\
\hline (Species effect $\cup$ Site effect $)=[\mathrm{A}+\mathrm{B}+\mathrm{C}]$ & 9 & 74 \\
\hline Species $\mid$ Site effect $=[\mathrm{A}]($ Site effect as covariable) & 6 & 19 \\
\hline Site effect $\mid$ species $=[\mathrm{C}]($ Species as covariable) & 3 & 8 \\
\hline $\begin{array}{c}\text { Species effect } \cap \text { Site effect }=[(\text { Species effect } \cup \text { Site effect })- \\
(\text { Species effect } \mid \text { Site effect })-(\text { Site effect } \mid \text { Species effect })]=[B]\end{array}$ & 0 & $74-(19)-(8)=47$ \\
\hline Residuals $=[$ Total inertia $-($ Species effect $\cup$ Site effect $)]$ & 0 & $100-74=26$ \\
\hline
\end{tabular}

\section{Discussion}

While in most deep aquatic ecosystems, meiofauna and microbial communities are drivers of benthic processes, in coastal estuarine systems macrofauna play a major role in organic matter mineralization and nutrient cycling [8,58-60]. The analysis of macrofauna diversity, abundance, functional role, and distribution is therefore central to understand coastal lagoon functioning [16,24]. The latter can be defined as the capacity of sediments to process organic matter inputs, avoiding excess carbon accumulation and resulting in fast nutrient turnover. Excluding the autotrophic component, benthic functioning in an eutrophic ecosystem with large $\mathrm{N}$ excess can also be defined as the degree of coupling of microbial processes (e.g., ammonification, nitrification, and denitrification) that results in net $\mathrm{N}$ loss and limited regeneration to the water column [61,62]. In present study, we did not characterize organic matter input to sediments and we cannot calculate the balance between input and output terms; however, we can reconstruct some paths of benthic $\mathrm{N}$ cycle and speculate on the role of macrofauna as regulator of microbially mediated N-processes.

\subsection{Physico-Chemical Zonation and Macrofauna Composition}

The four studied dominating areas of the lagoon revealed to be distinct environments, differing in sediment type, organic matter content, average salinity, and bottom water nutrient concentration (Table 1). Despite its small size, the Sacca di Goro Lagoon has a marked zonation that depends on the freshwater inputs, sea-lagoon water exchange, the extent of primary production, and deposition rates $[43,44,47,48]$. The observed difference in a number of bottom macrofauna species and functional traits (Figure 2) is most likely related to these environmental differences.

Freshwater input is the main driver of benthic ecosystem functioning in site 1, where nutrient loads affect rates and direction of the benthic solute fluxes. Intensive discharge transports sediment-bound nutrients (particularly phosphorus and silica), as well as dissolved inorganic nutrients such as $\mathrm{NO}_{3}{ }^{-}$, due to its high solubility and mobility. Due to shallow depths, most allochthonous particulate matter settles on surface sediment, where it is mineralized to inorganic nutrients. Dissolved nutrients from bottom water accumulate in pore water due to gradient driven diffusive transport, resulting in deep penetration of electron acceptors (e.g., $\mathrm{NO}_{3}{ }^{-}$) [40]. Due to tidal exchange and freshwater flushing from the Po di Volano River, a major portion of macrofauna biomass mainly consists of sediment dwelling 
opportunistic species, such as spionids, oligochaetes, and M. insidiosum, tolerant to high organic matter content and lower $\mathrm{O}_{2}$ concentration [63].

In the sheltered accumulation area (site 2), mainly autochthonous organic matter inputs (macroalgae and phytoplankton) are delivered by dominating hydrodynamic circulation. Such conditions favor the development of a thick layer of organic matter on the surface sediment and limits $\mathrm{O}_{2}$ or $\mathrm{NO}_{3}{ }^{-}$sediment penetration [38]. As a consequence, the dominant pathways of anaerobic respiration lead to the accumulation of reduced metabolites such as sulfides and $\mathrm{NH}_{4}{ }^{+}$, which are toxic for living macrofauna. This may explain the lack of macroinvertebrates other than M. insidiosum and C. salinarius.

Site 3 is located within the clams farming area. Our findings are consistent with results from previous surveys $[48,64,65]$, which show that the most diverse benthic community is generally found in the central-western part of the lagoon. Clams farming operations may lead to a moderate or high disturbance of benthic community [36], setting to zero the competitive advantages of potentially dominant species. High densities of filter-feeders produce changes in sediment physico-chemical characteristics, as organic enrichment that may favor the proliferation of small-sized tolerant macrofauna [66,67]. High clams density results also in large stimulation of $\mathrm{O}_{2}$ and $\mathrm{NH}_{4}{ }^{+}$fluxes due to combination of respiration, labile particles mineralization, and direct excretion $[29,46]$.

Site 4 is a sandy area exposed to tidal forcing and strong currents that prevent organic matter accumulation and restrict macrofauna distribution $[68,69]$. We speculate that macrofauna community composition at this marine site is shaped by hydrodynamic condition and sedimentary features. The limited organic pool in the sediments and the low concentrations of suspended matter in the water column result in a diversified benthic community but with low densities (Figure 2). Spionids are abundant at this site as this taxa prefers sandy substratum and tolerates wide salinity variations $[65,70]$.

\subsection{Macrofauna Affect Benthic Metabolim and N-Cyling across Sites}

In the Sacca di Goro Lagoon, as in other eutrophic estuarine systems, low $\mathrm{O}_{2}$ levels and anoxic crises are frequent and may affect the whole system functioning [37,71]. Due to the shallowness of the lagoon, $\mathrm{O}_{2}$ dynamics in the water column is primarily driven by benthic metabolism. Although rates of benthic $\mathrm{O}_{2}$ uptake were similar at the sites 1,2 , and $3\left(5 \mathrm{mmol} \mathrm{m}^{-2} \mathrm{~h}^{-1}\right.$ on average), we speculate that mechanisms underlying oxygen consumption were different. At the first two sites, re-oxidation of anaerobic metabolism end-products (e.g., free sulfides, ferrous iron, or manganous manganese) was likely an important sink for $\mathrm{O}_{2}$, whereas at the other sites, respiration by benthic organism was the dominant oxygen-consuming path.

We tentatively reconstructed the benthic $\mathrm{N}$-cycling from combined measured fluxes and calculated processes at each site. Benthic N-cycling consists of multiple processes, mostly mediated by bacteria, but strongly influenced by the presence and the activity of macrofauna. We therefore tried to explain at each site how macrofauna community drives $\mathrm{N}$ paths (Figure 7).

At site 1, a high efflux of $\mathrm{NO}_{3}{ }^{-}$suggests high rates of $\mathrm{NH}_{4}{ }^{+}$oxidation via nitrification which is tightly coupled to ammonification. This idea is supported by large $\mathrm{NO}_{3}{ }^{-}$efflux and negligible $\mathrm{NH}_{4}{ }^{+}$release from sediments. A major percentage of $\mathrm{NO}_{3}{ }^{-}(86 \%)$ produced via sediment nitrification accumulates in near-bottom water and only a small amount diffuses to anoxic sediments where it is denitrified (12\%). The results from the RDA stress the strong positive relationship among burrowing organism abundance at the site 1 and the measured $\mathrm{TCO}_{2}, \mathrm{NH}_{4}{ }^{+}$, and $\mathrm{NO}_{\mathrm{x}}{ }^{-}$fluxes (Figure 5). Abundant $M$. insidiosum and polychaete populations are able to create a dense network of burrows which extend the surface for solute exchange and the volume of oxic niches, stimulating bacterial activity. Furthermore, continuous ventilation of burrows by $M$. insidiosum supports nitrification process that requires $\mathrm{O}_{2}$ and $\mathrm{CO}_{2}$ [35]. Therefore, in this type of sediments, $\mathrm{CO}_{2}$ production via mineralization is likely offset by high nitrifiers assimilation. We also expect synergetic effect of spionids and M. insidiosum on nitrification. Spionids, which typically burrow deeper than M. insidiosum, enhance $\mathrm{NH}_{4}{ }^{+}$mobilization from deeper sediment layers to the surface horizons [72,73]. Here, $\mathrm{NH}_{4}{ }^{+}$ 
is oxidized to $\mathrm{NO}_{3}{ }^{-}$in burrows of M. insidiosum. Moares et al. [35] showed that the production of $\mathrm{NO}_{3}{ }^{-}$is significantly correlated with the abundance of $M$. insidiosum. As a result, nitrification largely prevails over denitrification in this type of habitat. However, low denitrification efficiency suggests that nitrification and denitrification are spatially uncoupled processes because of active burrow ventilation and the thickness of the oxic zone. The diffusion path of $\mathrm{NO}_{3}{ }^{-}$from the water column to the anoxic denitrification zone is so thick that Dw is significantly reduced, despite high water column $\mathrm{NO}_{3}{ }^{-}$concentration. Modelled rates of $\mathrm{Dw}$ are in fact much higher than measured rates ( 829 versus $153 \mu \mathrm{mol} \mathrm{m}{ }^{-2} \mathrm{~h}^{-1}$ [57]). We calculated that only $6 \%$ of the water column $\mathrm{NO}_{3}{ }^{-}$pool (assuming $1 \mathrm{~m}$ depth) is denitrified per day.
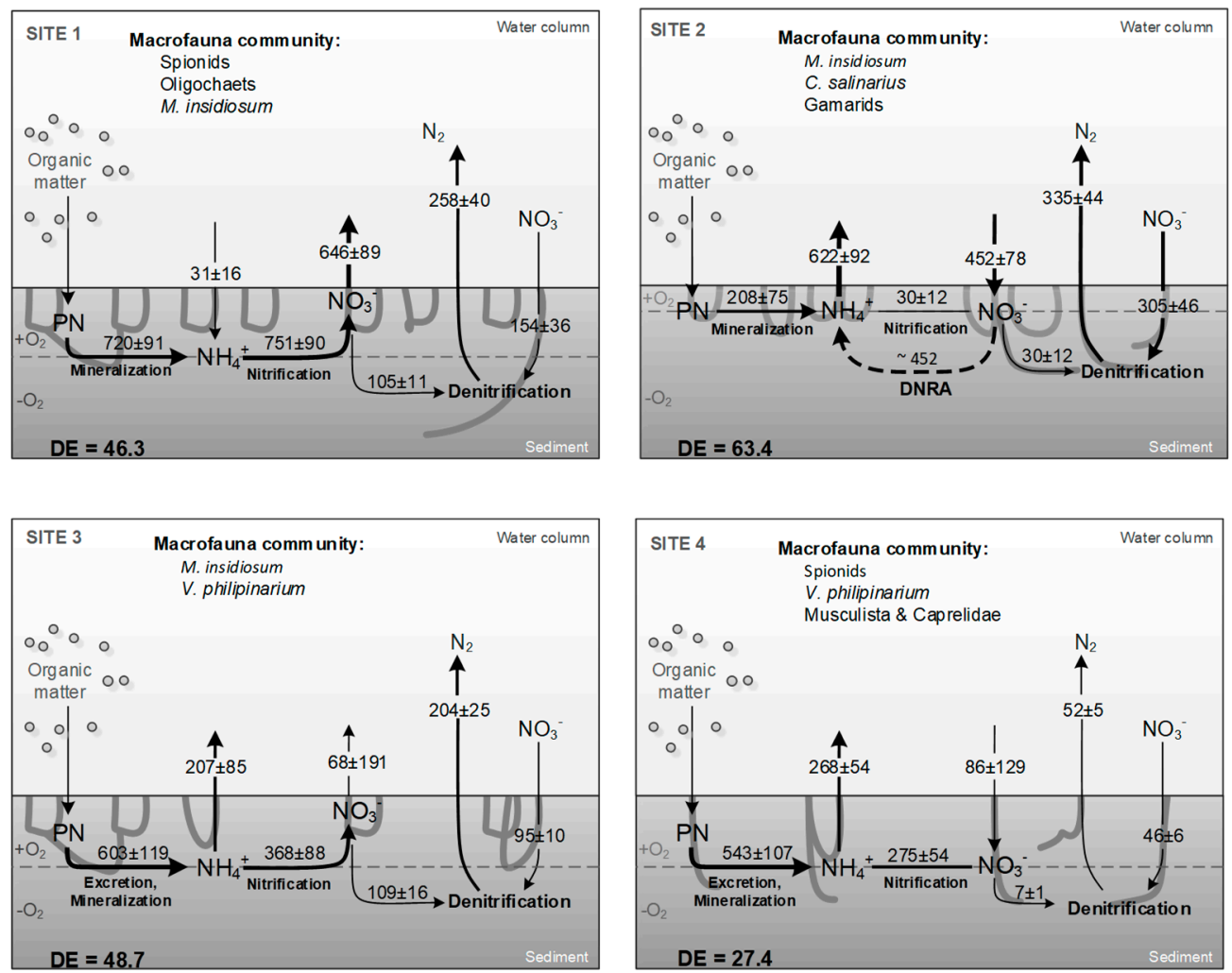

Figure 7. Flow scheme for benthic nitrogen $(\mathrm{N})$ pathways for each site, which were calculated from combinations of measured fluxes and process rates. The mineralization of organic $\mathrm{N}$ was estimated as the sum of net $\mathrm{NH}_{4}{ }^{+}$and $\mathrm{NO}_{3}{ }^{-}$efflux and nitrification coupled to denitrification (Dn); nitrification rates were estimated as the sum of the net $\mathrm{NO}_{3}{ }^{-}$efflux and $\mathrm{Dn}$; net $\mathrm{NO}_{3}{ }^{-}$efflux is the sum of measured $\mathrm{NO}_{3}{ }^{-}$efflux and denitrification based on bottom water $\mathrm{NO}_{3}{ }^{-}$. The mean rates (average \pm st. error) are expressed on an hourly basis per unit of sediment surface $\left(\mu \mathrm{mol} \mathrm{m}{ }^{-2} \mathrm{~d}^{-1}\right)$. Dissimilative $\mathrm{NO}_{3}{ }^{-}$ reduction to $\mathrm{NH}_{4}{ }^{+}$(DNRA) was not measured but is represented as a dotted line, a likely occurring path at site 2. Denitrification efficiency (DE) is the ratio between dinitrogen $\left(\mathrm{N}_{2}\right)$ flux and the sum of $\mathrm{N}_{2}$ and dissolved inorganic $\mathrm{N}\left(\mathrm{NH}_{4}{ }^{+}+\mathrm{NO}_{x}{ }^{-}\right)$effluxes.

At site 2, the sedimentary environment was chemically reduced as suggested by black color, smell of sulfides, and high $\mathrm{Mn}^{2+}$ efflux. This indicates the dominance of anaerobic respiration (e.g., metal reduction) with subsequent accumulation of $\mathrm{Fe}^{2+}, \mathrm{Mn}^{2+}$ and $\mathrm{H}_{2} \mathrm{~S}$ in bottom water. Measured high concentration of $\mathrm{Mn}^{2+}$ suggests an intensive manganese hydrooxides recycling. In coastal sediments, manganese hydrooxides can be either reduced to $\mathrm{Mn}^{2+}$ through microbial respiration or by the chemical oxidation of reduced iron and sulfur species [74,75]. In such $\mathrm{O}_{2}$-poor sediments, the reduction of metal hydrooxides with subsequent SRP mobilization to pore and adjacent bottom water is frequently observed [76]. Macrofauna community in this part of the lagoon mostly consists of small-sized surface burrowers such as C. salinarius, M. insidiosum, and gammarids. Ventilation of burrows by these 
specimens can also enhance exchange of microbial metabolism end-products. RDA analysis shows macrofauna functional traits being related to the SRP, $\mathrm{Mn}^{2+}$, and $\mathrm{NH}_{4}{ }^{+}$release from sediment and $\mathrm{N}$ loss via denitrification (Dw). Previous studies showed minor or negligible effect of these macrofauna taxa on nitrification and subsequently its coupling to denitrification in the burrow walls [77]. At site 2, ammonification is the dominant pathway within the $\mathrm{N}$ cycle. Relatively large amount of regenerated $\mathrm{NH}_{4}{ }^{+}(94 \%)$ accumulates in bottom water. The thin oxic sediment layer constrains nitrification process in the upper sediment layer, and thus rates are uncoupled to those of ammonification. We speculate that the limited $\mathrm{O}_{2}$ penetration results in a short path to get to the anoxic layer, and as a result denitrification is mainly fueled by water column $\mathrm{NO}_{3}{ }^{-}\left(92 \%\right.$ of $\mathrm{N}_{2}$ production) which reduces up to $18 \%$ of the nitrate pool in water. We also speculate that at this site $\mathrm{NO}_{3}{ }^{-}$reduction to $\mathrm{NH}_{4}{ }^{+}$could play an important role as nitrate sink and ammonium source. The comparison between macrofauna effects at sites 1 and 2 reveals that $M$. insidiosum can produce contrasting effects depending on site-specific features. If a fraction of the $\mathrm{NH}_{4}{ }^{+}$flux measured at the site 2 is driven by dissimilative $\mathrm{NO}_{3}{ }^{-}$reduction to $\mathrm{NH}_{4}{ }^{+}$ (DNRA) rather than organic matter mineralization, part of the $\mathrm{NO}_{3}{ }^{-}$flux to sediment could be recycled as $\mathrm{NH}_{4}{ }^{+}$(Figure 7). The specific conditions of site 2 result in much higher denitrification efficiency.

We assume that at site 3, where high macrofauna biomass was observed, $\mathrm{O}_{2}$ is respired by benthic macrofauna itself. According to [46], V. philippinarum, which is abundant at this site, contributes to a significant part of $\mathrm{O}_{2}$ uptake and $\mathrm{TCO}_{2}$ production. In addition, clams alone can excrete SRP and such direct excretion may account for up to $90 \%$ of the net flux measured during summer $[39,78]$. SRP fluxes can be sustained also by deposition and subsequent mineralization of feces [76]. Limited SRP fluxes in clams farming areas can be surprising, but the co-presence of clams and M. insidiosum may provide a reasonable explanation. SRP directly or indirectly produced by clams might in fact be transported within $M$. insidosum burrows during its ventilation and trapped through co-precipitation with metal hydrooxides. The same clams-amphipods association may result in coupled rates of ammonification, nitrification, and denitrification, promoting N-loss.

Our results suggest that clams also influence N-cycling in the followings ways: (i) directly by sediment bioturbation and (ii) indirectly by filtration and biodeposition of organic matter from water column to bottom sediments. V. philippinarum can be considered as shallow-burrower rather than deep-burrower but its bioturbation activity is strongly correlated to denitrification process (Dn in particular, see Figure 7). At this site, nearly $61 \%$ of sedimentary $\mathrm{NH}_{4}{ }^{+}$is oxidized to $\mathrm{NO}_{3}{ }^{-}$within the sediment and subsequently almost the entire pool is denitrified to $\mathrm{N}_{2}$. Approximately $62 \%$ of the total denitrification comes from the coupled nitrification-denitrification process. The direct stimulation of $\mathrm{N}$ processes, in particular nitrification, is likely due to additional habitat provided by burrow walls. The syphons of $V$. philippinarum provide a microoxic environment within sediments, which may support the activity of nitrifiers [39]. In addition, clams can excrete relevant amount of $\mathrm{NH}_{4}{ }^{+}, \mathrm{which}$ accounts up to $80 \%$ of overall sediment $\mathrm{N}$-regeneration [46]. A large part of $\mathrm{NH}_{4}{ }^{+}$is nitrified while the remaining fraction is released to bottom water. The high abundance of $M$. insidiosum at site 3 can support also nitrification and can be explained by the presence of clams, as these filter-feeders may provide high quality food for the amphipod [79].

The lowest respiration with respect to $\mathrm{O}_{2}$ uptake and $\mathrm{TCO}_{2}$ production was found at site 4 , where sediment is poor in organic matter and macrofauna is characterized by low biomass and by high number of functional traits: filter-feeders, deep burrowers, and scrapers. The balanced $\mathrm{O}_{2}$ uptake and $\mathrm{TCO}_{2}$ production suggest dominating aerobic respiration. In this hydrodynamic active area, sediment is always a sink for SRP due to high $\mathrm{O}_{2}$ penetration, which enhance buffer capacity, and microphytobenthos uptake [80]. Continuous current exposure and sediment erosion prevent organic matter accumulation and enhance pore water advection. Hence, low mineralization and end-product oxidation as $\mathrm{NH}_{4}{ }^{+}$via nitrification is expected. Surprisingly, we observed a relatively higher $\mathrm{NH}_{4}{ }^{+}$ efflux in comparison to site 3, where sediment also is poor in organic matter but host clams. At this site, nearly $98 \%$ of sedimentary $\mathrm{NH}_{4}{ }^{+}$is released to the bottom water while negligible amount is oxidized to $\mathrm{NO}_{3}{ }^{-}$within the sediment, which later is completely denitrified to $\mathrm{N}_{2}$. Since sediment is poor in 
organic matter, it is difficult to explain $\mathrm{NH}_{4}{ }^{+}$efflux by mineralization. Closer inspection of each single core suggests that the highest $\mathrm{NH}_{4}{ }^{+}$effluxes largely coincided with presence of musculista and partly of V. philippinarum, while spionids have a less evident effect. It seems likely that $\mathrm{NH}_{4}{ }^{+}$excreted by musculista is not directly incorporated into the benthic microbial communities at such sites under high hydrodynamic activity. Approximately $88 \%$ of the total denitrification is fueled by $\mathrm{NO}_{3}{ }^{-}$from overlaying water, however, the denitrification rates were the lowest as compared to the other sites. Due to high $\mathrm{NH}_{4}{ }^{+}$efflux and low denitrification rates, denitrification efficiency was low.

\subsection{Conclusions}

Predicting the effect of macrofauna diversity on benthic functioning can be critically important, given present threats to biological diversity such as habitat destruction, loss of species, overharvesting, and climate change. In the present work, we demonstrate that the relationships between biodiversity and benthic functioning can be tackled with multiple approaches on natural, undisturbed sediments collected along estuarine gradients. Multivariate analysis performed on single cores, each with a specific community and metabolic rates, provide a statistical evidence on how macrofaunal species drive sedimentary processes. The analysis of benthic $\mathrm{N}$-cycling conducted at a larger scale, grouping cores collected from the same site, allows to analyze how the interactions among different macrofauna groups determine different net effects on multiple microbial process. The combination of results from the two approaches allows in turn to speculate on underlying, macrofauna-mediated processes. Our results suggest the occurrence of complex relationships among the physical environment, the microbial communities and the macrofauna groups, exemplified by very different, macrofauna-community-dependent $\mathrm{N}$ paths. Such complex relationships cannot be evaluated in reconstructed sediment with single species, which provide very partial understanding of what happens in nature. Surface and deep burrowing organisms provide key ecosystem services in eutrophic shallow lagoon as they favor the oxidation of anaerobic path end-products, maintain active geochemical buffers (e.g., against sulfides or SRP release), and prevent excess decrease of sediment redox, resulting in negative feedbacks for macrofauna diversity. Cultivated clams are generally considered as nutrient sources due to their elevated excretion rates and biodeposits, but our results suggest that the co-occurrence of bivalves and burrowing organisms may promote nitrate loss via denitrification coupled to nitrification. Our approach can be extended to manipulative studies in which different macrofauna species can be added or removed in order to test specific hypotheses.

Supplementary Materials: The following are available online at http://www.mdpi.com/2073-4441/11/6/1186/s1.

Author Contributions: Conceptualization, M.B., T.P.; methodology, M.B.; formal analysis, D.D., T.P.; investigation, D.D., M.B., M.Z.; resources, G.C.; data curation, T.P., D.D.; writing-original draft preparation, T.B.; writing-review and editing, D.D., G.C., M.B., M.Z.

Funding: This research was supported by the Doctorate Study Programme in Ecology and Environmental Sciences, Klaipeda University, and by "Invertebrate-Bacterial Associations as Hotpots of Benthic Nitrogen Cycling in Estuarine Ecosystems (INBALANCE)" project which is funded by the European Social Fund according to the activity "Improvement of researchers qualification by implementing world-class R\&D projects of Measure", grant No. 09.3.3-LMT-K-712-01-0069.

Acknowledgments: We gratefully thank Irma Vybernaite-Lubiene, Fabio Vicenzi, and Tomas Ruginis for their assistance in field sampling and laboratory analysis.

Conflicts of Interest: The authors declare no conflict of interest.

\section{References}

1. Hargrave, B. Oxidation-Reduction Potentials, Oxygen Concentration and Oxygen Uptake of Profundal Sediments in a Eutrophic Lake. Oikos 1972, 23, 167-177. [CrossRef]

2. Lewandowski, J.; Hupfer, M. Effect of macrozoobenthos on two-dimensional small-scale heterogeneity of pore water phosphorus concentrations in lake sediments: A laboratory study. Limnol. Oceanogr. 2005, 50, 1106-1118. [CrossRef] 
3. Volkenborn, N.; Polerecky, L.; Hedtkamp, S.I.C.; van Beusekom, J.E.; De Beer, D. Bioturbation and bioirrigation extend the open exchange regions in permeable sediments. Limnol. Oceanogr. 2007, 52, 1898-1909. [CrossRef]

4. Kristensen, E.; Penha-Lopes, G.; Delefosse, M.; Valdemarsen, T.; Quintana, C.O.; Banta, G.T. What is bioturbation? The need for a precise definition for fauna in aquatic sciences. Mar. Ecol. Prog. Ser. 2012, 446, 285-302. [CrossRef]

5. Schaller, J. Bioturbation/bioirrigation by Chironomus plumosus as main factor controlling elemental remobilization from aquatic sediments? Chemosphere 2014, 107, 336-343. [CrossRef] [PubMed]

6. Aller, R.C.; Aller, J.Y. The effect of biogenic irrigation intensity and solute exchange on diagenetic reaction rates in marine sediments. J. Mar. Res. 1998, 56, 905-936. [CrossRef]

7. Kristensen, E.; Hansen, K. Transport of carbon dioxide and ammonium in bioturbated (Nereis diversicolor) coastal, marine sediments. Biogeochemistry 1999, 45, 147-168. [CrossRef]

8. Bonaglia, S.; Nascimento, F.A.; Bartoli, M.; Klawonn, I.; Brüchert, V. Meiofauna increases bacterial denitrification in marine sediments. Nat. Commun. 2014, 5, 5133. [CrossRef] [PubMed]

9. Carstensen, J.; Conley, D.J.; Bonsdorff, E.; Gustafsson, B.G.; Hietanen, S.; Janas, U.; Reed, D.C. Hypoxia in the Baltic Sea: Biogeochemical cycles, benthic fauna, and management. Ambio 2014, 43, 26-36. [CrossRef]

10. Geert Hiddink, J.; Wynter Davies, T.; Perkins, M.; Machairopoulou, M.; Neill, S.P. Context dependency of relationships between biodiversity and ecosystem functioning is different for multiple ecosystem functions. Oikos 2009, 118, 1892-1900. [CrossRef]

11. Magri, M.; Benelli, S.; Bondavalli, C.; Bartoli, M.; Christian, R.R.; Bodini, A. Benthic N pathways in illuminated and bioturbated sediments studied with network analysis. Limnol. Oceanogr. 2018, 63, S68-S84. [CrossRef]

12. Padilla, D.K.; Allen, B.J. Paradigm lost: Reconsidering functional form and group hypotheses in marine ecology. J. Exp. Mar. Biol. Ecol. 2000, 250, 207-221. [CrossRef]

13. Laverock, B.; Tait, K.; Gilbert, J.A.; Osborn, A.M.; Widdicombe, S. Impacts of bioturbation on temporal variation in bacterial and archaeal nitrogen-cycling gene abundance in coastal sediments. Environ. Microbiol. Rep. 2014, 6, 113-121. [CrossRef] [PubMed]

14. Foshtomi, M.Y.; Braeckman, U.; Derycke, S.; Sapp, M.; Van Gansbeke, D.; Sabbe, K.; Vanaverbeke, J. The link between microbial diversity and nitrogen cycling in marine sediments is modulated by macrofaunal bioturbation. PLOS ONE 2015, 10, e0130116.

15. Vasquez-Cardenas, D.; Quintana, C.O.; Meysman, F.J.; Kristensen, E.; Boschker, H.T. Species-specific effects of two bioturbating polychaetes on sediment chemoautotrophic bacteria. Mar. Ecol. Prog. Ser. 2016, 549, 55-68. [CrossRef]

16. Kauppi, L.; Bernard, G.; Bastrop, R.; Norkko, A.; Norkko, J. Increasing densities of an invasive polychaete enhance bioturbation with variable effects on solute fluxes. Sci. Rep. 2018, 8. [CrossRef] [PubMed]

17. Prins, T.C.; Smaal, A.C.; Dame, R.F. A review of the feedbacks between bivalve grazing and ecosystem processes. Aquat. Ecol. 1997, 31, 349-359. [CrossRef]

18. Hakenkamp, C.C.; Palmer, M.A. Introduced bivalves in freshwater ecosystems: The impact of Corbicula on organic matter dynamics in a sandy stream. Oecologia 1999, 119, 445-451. [CrossRef]

19. Pelegri, S.P.; Blackburn, T.H. Bioturbation effects of the amphipod Corophium volutator on microbial nitrogen transformations in marine sediments. Mar. Biol. 1994, 121, 253-258. [CrossRef]

20. Pelegri, S.P.; Blackburn, T.H. Effect of bioturbation by Nereis sp., Mya arenaria and Cerastoderma sp. on nitrification and denitrification in estuarine sediments. Ophelia 1995, 42, 289-299. [CrossRef]

21. Haag, D.; Matschonat, G. Limitations of controlled experimental systems as models for natural systems: A conceptual assessment of experimental practices in biogeochemistry and soil science. Sci. Total Environ. 2001, 277, 199-216. [CrossRef]

22. Bonaglia, S. Benthic Metabolism and Sediment Nitrogen Cycling in Baltic Sea Coastal Areas: The Role of Eutrophication, Hypoxia and Bioturbation. Licentiate Thesis, Stockholm University, Stockholm, Sweden, 2012. Available online: http://urn.kb.se/resolve?urn=urn:nbn:se:su:diva-85261 (accessed on 18 December 2018).

23. Stocum, E.T.; Plante, C.J. The effect of artificial defaunation on bacterial assemblages of intertidal sediments. J. Exp. Mar. Biol. Ecol. 2006, 337, 147-158. [CrossRef]

24. Gammal, J.; Norkko, J.; Pilditch, C.A.; Norkko, A. Coastal hypoxia and the importance of benthic macrofauna communities for ecosystem functioning. Estuaries Coasts 2017, 40, 457-468. [CrossRef] 
25. Gammal, J.; Järnström, M.; Bernard, G.; Norkko, J.; Norkko, A. Environmental Context Mediates Biodiversity-Ecosystem Functioning Relationships in Coastal Soft-sediment Habitats. Ecosystems 2019, 22, 137-151. [CrossRef]

26. Gogina, M.; Lipka, M.; Woelfel, J.; Liu, B.; Böttcher, M.E.; Zettler, M.L. In search of a field-based relationship between benthic macrofauna and biogeochemistry in a modern brackish coastal sea. Front. Mar. Sci. 2018, 5, 489. [CrossRef]

27. Vybernaite-Lubiene, I.; Zilius, M.; Saltyte-Vaisiauske, L.; Bartoli, M. Recent trends (2012-2016) of N, Si, and P export from the Nemunas River Watershed: Loads, unbalanced stoichiometry, and threats for downstream aquatic ecosystems. Water 2018, 10, 1178. [CrossRef]

28. Vanni, M.J. Nutrient cycling by animals in freshwater ecosystems. Annu. Rev. Ecol. Syst. 2002, 33, 341-370. [CrossRef]

29. Murphy, A.E.; Nizzoli, D.; Bartoli, M.; Smyth, A.R.; Castaldelli, G.; Anderson, I.C. Variation in benthic metabolism and nitrogen cycling across clam aquaculture sites. Mar. Pollut. Bull. 2018, 127, 524-535. [CrossRef]

30. Asmala, E.; Carstensen, J.; Conley, D.J.; Slomp, C.P.; Stadmark, J.; Voss, M. Efficiency of the coastal filter: Nitrogen and phosphorus removal in the Baltic Sea. Limnol. Oceanogr. 2017, 62, S222-S238. [CrossRef]

31. Zilius, M.; Vybernaite-Lubiene, I.; Vaiciute, D.; Petkuviene, J.; Zemlys, P.; Liskow, I.; Bukaveckas, P.A. The influence of cyanobacteria blooms on the attenuation of nitrogen throughputs in a Baltic coastal lagoon. Biogeochemistry 2018, 141, 143-165. [CrossRef]

32. Dame, R.F. The role of bivalve filter feeder material fluxes in estuarine ecosystems. In Bivalve Filter Feeders; Springer: Berlin/Heidelberg, Germany, 1993; pp. 245-269.

33. Lohrer, A.M.; Thrush, S.F.; Gibbs, M.M. Bioturbators enhance ecosystem function through complex biogeochemical interactions. Nature 2004, 431, 1092. [CrossRef] [PubMed]

34. Stief, P. Stimulation of microbial nitrogen cycling in aquatic ecosystems by benthic macrofauna: Mechanisms and environmental implications. Biogeosciences 2013, 10, 7829-7846. [CrossRef]

35. Moraes, P.C.; Zilius, M.; Benelli, S.; Bartoli, M. Nitrification and denitrification in estuarine sediments with tube-dwelling benthic animals. Hydrobiologia 2018, 819, 217-230. [CrossRef]

36. Bartoli, M.; Nizzoli, D.; Viaroli, P.; Turolla, E.; Castaldelli, G.; Fano, E.A.; Rossi, R. Impact of Tapes philippinarum farming on nutrient dynamics and benthic respiration in the Sacca di Goro. Hydrobiologia 2001, 455, 203-212. [CrossRef]

37. Viaroli, P.; Azzoni, R.; Bartoli, M.; Giordani, G.; Tajé, L. Evolution of the trophic conditions and dystrophic outbreaks in the Sacca di Goro lagoon (Northern Adriatic Sea). In Mediterranean Ecosystems; Springer: Milano, Italy, 2001; pp. 467-475.

38. Viaroli, P.; Bartoli, M.; Azzoni, R.; Giordani, G.; Mucchino, C.; Naldi, M.; Tajé, L. Nutrient and iron limitation to Ulva blooms in a eutrophic coastal lagoon (Sacca di Goro, Italy). Hydrobiologia 2005, 550, 57-71. [CrossRef]

39. Nizzoli, D.; Bartoli, M.; Viaroli, P. Nitrogen and phosphorous budgets during a farming cycle of the Manila clam Ruditapes philippinarum: An In Situ experiment. Aquaculture 2006, 261, 98-108. [CrossRef]

40. Zilius, M.; Giordani, G.; Petkuviene, J.; Lubiene, I.; Ruginis, T.; Bartoli, M. Phosphorus mobility under short-term anoxic conditions in two shallow eutrophic coastal systems (Curonian and Sacca di Goro lagoons). Estuar. Coast. Shelf Sci. 2016, 164, 134-146. [CrossRef]

41. Naldi, M.; Viaroli, P. Nitrate uptake and storage in the seaweed Ulva rigida C. Agardh in relation to nitrate availability and thallus nitrate content in a eutrophic coastal lagoon (Sacca di Goro, Po River Delta, Italy). J. Exp. Mar. Biol. Ecol. 2002, 269, 65-83. [CrossRef]

42. Ceccherelli, V.U.; Ceccherelli, G.C.; Reggiani, G.; Caramori, V.; Gaiani, C.; Corazza, C. Le comunità macrobentoniche della Sacca di Goro e gli effetti di disturbo ambientale; Risultate di due anni d'indagine (Dicembre 1987-Dicembre 1989). In Sacca di Goro: Studio Integrato Sull'ecologia; FrancoAngeli: Milano, Italy, 1994; pp. 83-108.

43. Mistri, M.; Rossi, R.; Fano, E.A. Structure and secondary production of a soft bottom macrobenthic community in a brackish lagoon (Sacca di Goro, north-eastern Italy). Estuar. Coast. Shelf Sci. 2001, 52, 605-616. [CrossRef]

44. Marinov, D.; Zaldívar, J.M.; Norro, A.; Giordani, G.; Viaroli, P. Integrated modelling in coastal lagoons: Sacca di Goro case study. Hydrobiologia 2008, 611, 147-165. [CrossRef]

45. Viaroli, P.; Giordani, G.; Bartoli, M.; Naldi, M.; Azzoni, R.; Nizzoli, D.; Ferrari, I. The Sacca di Goro lagoon and an arm of the Po River. In Estuaries; Springer: Berlin/Heidelberg, Germany, 2006; pp. 197-232. 
46. Nizzoli, D.; Bartoli, M.; Cooper, M.; Welsh, D.T.; Underwood, G.J.; Viaroli, P. Implications for oxygen, nutrient fluxes and denitrification rates during the early stage of sediment colonisation by the polychaete Nereis spp. in four estuaries. Estuar. Coast. Shelf Sci. 2007, 75, 125-134. [CrossRef]

47. Welsh, D.T.; Nizzoli, D.; Fano, E.A.; Viaroli, P. Direct contribution of clams (Ruditapes philippinarum) to benthic fluxes, nitrification, denitrification and nitrous oxide emission in a farmed sediment. Estuar. Coast. Shelf Sci. 2015, 154, 84-93. [CrossRef]

48. Mistri, M.; Fano, E.A.; Rossi, R. Redundancy of macrobenthos from lagoonal habitats in the Adriatic Sea. Mar. Ecol. Prog. Ser. 2001, 215, 289-296. [CrossRef]

49. Dalsgaard, T.; Nielsen, L.P.; Brotas, V.; Viaroli, P.; Underwood, G.; Nedwell, D.; Dong, L. Protocol Handbook for NICE-Nitrogen Cycling in Estuaries: A Project under the EU Research Programme: Marine Science and Technology (MAST III); Ministry of Environment and Energy National Environmental Research Institute: Silkeborg, Denmark, 2000; pp. 1-62.

50. Nielsen, L.P. Denitrification in sediment determined from nitrogen isotope pairing. FEMS Microbiol. Ecol. 1992, 9, 357-361. [CrossRef]

51. Kana, T.M.; Darkangelo, C.; Hunt, M.D.; Oldham, J.B.; Bennett, G.E.; Cornwell, J.C. Membrane inlet mass spectrometer for rapid high-precision determination of $\mathrm{N}_{2}, \mathrm{O}_{2}$, and $\mathrm{Ar}$ in environmental water samples. Anal. Chem. 1994, 66, 4166-4170. [CrossRef]

52. Grassshoff, K. Determination of nitrate. In Methods of Seawater Analysis; Grassoff, K., Ehrhardt, M., Kremling, K., Eds.; Verlag Chemie: Weinheimm, Germany, 1982; p. 143.

53. Legendre, P.; Legendre, L. Complex ecological data sets. In Developments in Environmental Modelling; Elsevier: Amsterdam, The Netherlands, 2012; Volume 24, pp. 1-57.

54. Zuur, A.; Ieno, E.N.; Smith, G.M. Analyzing Ecological Data; Springer Science \& Business Media: Berlin/Heidelberg, Germany, 2007.

55. Zar, J.H. Biostatistical Analysis; Prentice Hall: Upper Saddle River, NJ, USA, 1999.

56. Bray, J.R.; Curtis, J.T. An ordination of the upland forest communities of southern Wisconsin. Ecol. Monogr. 1957, 27, 325-349. [CrossRef]

57. Christensen, P.B.; Nielsen, L.P.; Sørensen, J.; Revsbech, N.P. Denitrification in nitrate-rich streams: Diurnal and seasonal variation related to benthic oxygen metabolism. Limnol. Oceanogr. 1990, 35, 640-651. [CrossRef]

58. Norling, K.; Rosenberg, R.; Hulth, S.; Grémare, A.; Bonsdorff, E. Importance of functional biodiversity and species-specific traits of benthic fauna for ecosystem functions in marine sediment. Mar. Ecol. Prog. Ser. 2007, 332, 11-23. [CrossRef]

59. Braeckman, U.; Provoost, P.; Gribsholt, B.; Van Gansbeke, D.; Middelburg, J.J.; Soetaert, K.; Vanaverbeke, J. Role of macrofauna functional traits and density in biogeochemical fluxes and bioturbation. Mar. Ecol. Prog. Ser. 2010, 399, 173-186. [CrossRef]

60. Nascimento, F.J.; Näslund, J.; Elmgren, R. Meiofauna enhances organic matter mineralization in soft sediment ecosystems. Limnol. Oceanogr. 2013, 57, 338-346. [CrossRef]

61. Ferguson, A.; Eyre, B. Interaction of benthic microalgae and macrofauna in the control of benthic metabolism, nutrient fluxes and denitrification in a shallow sub-tropical coastal embayment (western Moreton Bay, Australia). Biogeochemistry 2013, 112, 423-440. [CrossRef]

62. Griffiths, N.A.; Jackson, C.R.; McDonnell, J.J.; Klaus, J.; Du, E.; Bitew, M.M. Dual nitrate isotopes clarify the role of biological processing and hydrologic flow paths on nitrogen cycling in subtropical low-gradient watersheds. J. Geophys. Res. Biogeosci. 2016, 121, 422-437. [CrossRef]

63. Mosbahi, N.; Blanchet, H.; Lavesque, N.; De Montaudouin, X.; Dauvin, J.C.; Neifar, L. Main Ecological Features of Benthic Macrofauna in Mediterranean and Atlantic Intertidal Eelgrass Beds: A Comparative Study. J. Mar. Biol. Oceanogr. 2017, 6, 100174. [CrossRef]

64. Sousa, W.P. Disturbance in marine intertidal boulder fields: The nonequilibrium maintenance of species diversity. Ecology 1979, 60, 1225-1239. [CrossRef]

65. Sousa, W.P. Experimental investigations of disturbance and ecological succession in a rocky intertidal algal community. Ecol. Monogr. 1979, 49, 227-254. [CrossRef]

66. Forrest, B.M.; Keeley, N.B.; Hopkins, G.A.; Webb, S.C.; Clement, D.M. Bivalve aquaculture in estuaries: Review and synthesis of oyster cultivation effects. Aquaculture 2009, 298, 1-15. [CrossRef]

67. Bartoli, M.; Castaldelli, G.; Nizzoli, D.; Fano, E.A.; Sousa, P. Manila clam introduction in the Sacca di Goro Lagoon (Northern Italy): Ecological implications. Bull. Jpn. Fish. Res. Educ. Agen. 2016, 42, 43-52. 
68. Hall, S.J. Physical disturbance and marine benthic communities: Life in unconsolidated sediments. Oceanogr. Mar. Biol. Annu. Rev. 1994, 32, 179-239.

69. Norkko, A.; Thrush, S.F.; Hewitt, J.E.; Cummings, V.J.; Norkko, J.; Ellis, J.I.; MacDonald, I. Smothering of estuarine sandflats by terrigenous clay: The role of wind-wave disturbance and bioturbation in site-dependent macrofaunal recovery. Mar. Ecol. Prog. Ser. 2002, 234, 23-42. [CrossRef]

70. Dauer, D.M.; Rodi, A.J.; Ranasinghe, J.A. Effects of low dissolved oxygen events on the macrobenthos of the lower Chesapeake Bay. Estuaries 1992, 15, 384-391. [CrossRef]

71. Zilius, M.; Bartoli, M.; Bresciani, M.; Katarzyte, M.; Ruginis, T.; Petkuviene, J.; Razinkovas-Baziukas, A. Feedback mechanisms between cyanobacterial blooms, transient hypoxia, and benthic phosphorus regeneration in shallow coastal environments. Estuaries Coasts 2014, 37, 680-694. [CrossRef]

72. Mermillod-Blondin, F.; Rosenberg, R.; François-Carcaillet, F.; Norling, K.; Mauclaire, L. Influence of bioturbation by three benthic infaunal species on microbial communities and biogeochemical processes in marine sediment. Aquat. Microb. Ecol. 2004, 36, 271-284. [CrossRef]

73. Quintana, C.O.; Hansen, T.; Delefosse, M.; Banta, G.; Kristensen, E. Burrow ventilation and associated porewater irrigation by the polychaete Marenzelleria viridis. J. Exp. Mar. Biol. Ecol. 2011, 397, 179-187. [CrossRef]

74. Thamdrup, B.; Fossing, H.; Jørgensen, B.B. Manganese, iron and sulfur cycling in a coastal marine sediment, Aarhus Bay, Denmark. Geochim. Cosmochim. Acta 1994, 58, 5115-5129. [CrossRef]

75. Schippers, A.; Jørgensen, B.B. Oxidation of pyrite and iron sulfide by manganese dioxide in marine sediments. Geochim. Cosmochim. Acta 2001, 65, 915-922. [CrossRef]

76. Azzoni, R.; Giordani, G.; Viaroli, P. Iron-sulphur-phosphorus interactions: Implications for sediment buffering capacity in a mediterranean eutrophic lagoon (Sacca di Goro, Italy). Hydrobiologia 2005, 550, 131-148. [CrossRef]

77. Pelegri, S.P.; Blackburn, T.H. Effects of Tubifex tubifex (Oligochaeta: Tubificidae) on N-mineralization in freshwater sediments, measured with $15 \mathrm{~N}$ isotopes. Aquat. Microb. Ecol. 1995, 9, 289-294. [CrossRef]

78. Magni, P.; Montani, S.; Takada, C.; Tsutsumi, H. Temporal scaling and relevance of bivalve nutrient excretion on a tidal flat of the Seto Inland Sea, Japan. Mar. Ecol. Prog. Ser. 2000, 198, 139-155. [CrossRef]

79. Graf, G.; Rosenberg, R. Bioresuspension and biodeposition: A review. J. Mar. Syst. 1997, 11, 269-278. [CrossRef]

80. Sundbäck, K.; Miles, A.; Göransson, E. Nitrogen fluxes, denitrification and the role of microphytobenthos in microtidal shallow-water sediments: An annual study. Mar. Ecol. Prog. Ser. 2000, 200, 59-76. [CrossRef] 